\title{
Students' Perception of the Influence of Environmental Characteristics on the Academic Performance of Students in Integrated Science in Rivers State
}

\author{
Iweka, Fidelis (Ph.D) \\ Department of Educational Psychology, Guidance and Counselling, University of Port Harcourt, Rivers State, \\ Nigeria \\ *Corresponding Authors: Iweka, Fidelis (Ph.D), Department of Educational Psychology, Guidance and \\ Counselling, University of Port Harcourt, Rivers State, Nigeria. Email: iwekafidel@gmail.com
}

\begin{abstract}
The study investigated the efficacy of the students' perception of the influence of environmental characteristics on the academic performances of students in integrated science in Rivers State of Nigeria. Two hypotheses were formulated and tested in the course of the study. 600 junior secondary school 3 students (J.S.S. 3) were stratified and randomly selected from 300 junior secondary schools of the 359 junior secondary schools in Rivers State as at the time of the study. The sample was equally distributed among the male and female students. The student questionnaire and integrated science achievement test were used as data collecting instruments. The data collected was analyzed with the aid of the Z-test statistic and Pearson Product Moment correlation. It was found out that females performed better than their male counterparts and that environmental characteristic influenced their learning outcomes. It was then concluded that performance of students in integrated science is influenced by the environmental characteristics and recommended that stakeholders in education industry should meet constantly to discus issues concerning the teaching and learning environment of students particularly in integrated science at junior secondary school levels.
\end{abstract}

Keywords: Student's Perception, Environmental Characteristics, Academic Performance and Integrated Science.

\section{INTRODUCTION}

The need to improve the performance of students in Junior Secondary School certificate examination among integrated science educators and other teachers has grown considerably over the past decade. The federal government has spent so much funds towards the research and development of integrated science curriculum in recent years.

The realities of modern world and rapid social changes and the kind of what the society desired in relation to the environment has made it paramount that development, it must take into consideration the principles and practice of science. [1] pointed out that "countries in Africa are going through rapid period of transformation and the principles and inventions of science and technology play a major role in the process of development".

Realizing this important contribution of science in national development, the federal government laid emphasis on the importance of science and technology and in [2] stated among other things that:

(1) a greater proportion of education expenditure will be devoted to science and technology; and

(2) universities and other levels of education system will be required to pay greater attention to the development of scientific orientation. The ratio of Science to liberal Arts students in our universities has been fixed at 60:40 during the third national Development plan period. With regard to the above, [3] stated that the principal aim of the 9-3-4 system of education is education in science and technology as a means of accelerating national development. This emphasis on science and technology led to an important academic revolution in which the focus drifted from the study of general science to integrated science. The adoption of this change is predicated on the fact that integrated science is considered to be more relevant to the child and the society than the general science. The essence of integrated science as stated in the National curriculum for Junior Secondary Schools, volume 1: science (1984:3) is to enable the child among others, (a) gain the concept of the 
fundamental unity of science (b) gain the commonality of approach to problem of a scientific nature. (c) gain an understanding of the role, function of science in everyday life, and the world in which he/she lives. To show the usefulness, need and applicability of science, the subject, integrated science, was made compulsory at the Junior Secondary School by making it one of the core subjects.

In spite of the new curriculum, qualified trained teachers and improved environment, the optimum expections for students' improving in their academic performance have hardly been achieved. The woeful performance of students in integrated science in the Junior Secondary School certificate has given room for serious complaints from all stakeholders over the past few years. A number of studies have been carried out to find out the major causal factors of students poor academic performance other than the factor students mental ability.

[4] indicates that environment plays significant role in the learning behavior of the students. Apart from hereditary factors which are transmitted from parents to children, environmental influence is considered as a factor that may either promote or endanger the academic pursuit of the learner.

[5], without a shadow of doubt, says the environment characteristics of the learner have a great correlation with the learners academic attainment. Provision of instructional aids has often been considered as a necessity for better academic performance of the learner. Several schools of thought have advocated for improvement of our school environment. [6] is however, of a different view on this matter. He maintained that improvement of students' academic achievement must begin with the home. [7], opined that the factors of poor academic performance reside in the students, the teachers and home.

[8], identified two factors as being responsible for students poor performances in their junior secondary school certificate examination. The factors are family environment and teaching methods employed by the teachers in the schools. The junior secondary school certificate (JSSC) examination though an external examination is designed to prepare the individual for a vocation. It is meant to equip the individual for the task ahead particularly in the senior secondary schools. An educational objective is never said to be realized if the recipient of such education keep scoring very low marks in examinations. Efforts must be made to tackle this issue. It is in the light of this that the researcher wishes to examine the student's perception of environmental characteristics as related to their learning outcomes in integrated science in Junior Secondary Schools in Rivers State.

\subsection{Statement of the Problem}

Parents, teachers and students have continued to maintain different perception as to the causes of poor performance of students in the junior secondary school certificate (JSSC) examination in Rivers State. Some persons particularly the parents believe that the poor performance of students is a result of teachers' negligence, others strongly maintained that the half backed graduate teachers which our colleges of Education and universities produce today account for the poor performance of the students in examinations. No matter who is responsible for it, the consequences of this are enormous. The problem of the study therefore was to find out the influence of environmental characteristics on the academic performance of students in integrated science in JSS in Rivers State of Nigeria.

\subsection{Purpose of the Study}

The main purpose of the study was to find out the main environmental factors contributing to poor academic performance in integrated science among junior secondary school students as perceived by the students themselves. Specifically, the relationship between the environmental factors and student performance was also examined in relation to sex.

\subsection{Hypothesis}

The following hypotheses will guide the study. The two null hypotheses were formulated and tested in the course of the study.

- There is no significant difference between the mean perception scores of male and female students regarding the factors contributing to their poor achievement in integrated science.

- There is no significant correlation between the students' perception of environmental characteristics and their achievement in integrated science. 


\section{Methodology}

Survey research design was used for this study. All the junior secondary three (JS3) students in all the 359 public secondary schools in Rivers State at the time of the study formed the population of the study. Three hundred (300) junior secondary schools and two students from each of the schools were obtained using stratified random sampling method. The sample for this study was made up of 600 junior secondary three (JS 3) integrated science students. The sample was also distributed equally among male and female students. The students' questionnaire and integrated science achievement test were the two instruments developed by the researcher for the study. The students' questionnaire was made up of two sections (A) and (B). section A dealt with the personal data of the student (excluding name) and the school, while section B concentrated on the students perception of the environmental characteristics as related to their academic achievement in integrated science and the respondents (JS 3 students) were to tick agree, undecided or disagree. Agree will attract a score of 3 , undecided - a score of 2 and disagree - a score of 1 . Test - retest technique was used in determining the reliability of the students questionnaire.

Kuder - Richardson 21 formula was used to determine the reliability coefficient index of 0.81 (with 4 weeks interval) while Pearson's Product Moment Correlation Coefficient index of 0.79 was arrived at. Integrated science achievement test was made up of 50 items covering the syllabus for JS 1 and JS 2 . All the items were selected from the past JSS C examination in integrated science by the exams and records division of the Ministry of Education Port Harcourt. This explained why the item analyses (difficulty index discrimination index and distracter indices) of each item were not calculated. The two instruments were administered and collected after completion. The students were instructed not to write their names so that they can be free to express their candid options. Although the students were instructed not to write their names, the questionnaire was coded by the researcher for identification purposes. The Z-test statistic was used to analyze the mean perception scores for male and female students at 0.05 level of significance while Pearson Product Moment Correlation Coefficient was used for the analysis of the correlation between students perception of environmental characteristics and their achievement in integrated science. Z-test statistical technique was implored because the samples involved was large [9].

\section{RESUlTS}

Table1. Students' perception of the influence of Environmental characteristics on the academic performance of students in integrated science

\begin{tabular}{|l|l|l|l|}
\hline \multicolumn{1}{|c|}{ Level of opinion } & \multicolumn{1}{|c|}{ Score } & \multicolumn{1}{c|}{ No of students } & Percentage \% \\
\hline Agree & $60-72$ & 5.12 & 85.33 \\
\hline Undecided & $36-59.9$ & 64 & 10.66 \\
\hline Disagree & $24-35.9$ & 24 & 4.01 \\
\hline & Total & 600 & 100 \\
\hline
\end{tabular}

Table2. Sex distribution of students' perception of the influence of Environmental characteristics on the academic performance of students in integrated science

\begin{tabular}{|l|c|c|c|c|c|}
\hline \multirow{2}{*}{ Level of opinion } & \multirow{2}{*}{ Score } & \multicolumn{2}{c|}{ No of students } & \multicolumn{2}{c|}{ Percentage } \\
\cline { 3 - 6 } & & M & F & M & F \\
\hline Agree & $60-72$ & 243 & 269 & 81 & 89.67 \\
\hline Undecided & $36-59.9$ & 39 & 25 & 13 & 8.33 \\
\hline Disagree & $24-35.9$ & 18 & 6 & 6 & 2.00 \\
\hline & Total & 300 & 300 & 100 & 100 \\
\hline
\end{tabular}

$M=$ Male and $F=$ Female

Table3. Mean scores $(\bar{x})$ of students' perception in each item of the students' questionnaire.

\begin{tabular}{|c|c|c|c|c|c|c|c|c|c|c|}
\hline $\mathrm{S} / \mathrm{N}$ of Item & 1 & 2 & 3 & 4 & 5 & 6 & 7 & 8 & 9 & 10 \\
\hline Mean score $(\bar{x})$ & 2.7 & 2.5 & 1.3 & 1.3 & 2.9 & 1.2 & 2.5 & 1.8 & 2.8 & 1.3 \\
\hline $\mathrm{S} / \mathrm{N}$ of Item & 11 & 12 & 13 & 14 & 15 & 16 & 17 & 18 & 19 & 20 \\
\hline Mean score $(\bar{x})$ & 1.4 & 2.6 & 2.7 & 1.4 & 2.8 & 2.3 & 2.9 & 1.1 & 1.2 & 2.5 \\
\hline
\end{tabular}

Mean score of:

$2.5-3.0$ is an agreement with the opinion expressed 
Students' Perception of the Influence of Environmental Characteristics on the Academic Performance of Students in Integrated Science in Rivers State

$1.5-2.4$ is an uncertain feeling about the opinion

1.0-1.4 is disagreement with the opinion.

Table4. Performance of students in the integrated science achievement test

\begin{tabular}{|l|l|l|l|}
\hline \multicolumn{1}{|c|}{ Marks obtained } & \multicolumn{1}{|c|}{ Description } & No of students & \multicolumn{1}{c|}{$\%$} \\
\hline 60 and above & Very good & 55 & 9.16 \\
\hline $50-59.9$ & Good & 78 & 13.00 \\
\hline $40-49.9$ & Fair & 130 & 21.67 \\
\hline $0-39.9$ & Poor & 337 & 56.17 \\
\hline & Total & 600 & 100 \\
\hline
\end{tabular}

Table5. Performance of male and female students in the integrated science Achievement Test.

\begin{tabular}{|l|l|c|c|c|c|}
\hline \multirow{2}{*}{ Marks obtained } & \multirow{2}{*}{ Description } & No. of students & \multicolumn{2}{l|}{ Percentage } \\
\cline { 2 - 5 } & & $\mathbf{M}$ & $\mathbf{F}$ & $\mathbf{M}$ & F \\
\hline 60 and above & Very good & 25 & 30 & 8.33 & 10.00 \\
\hline $50-59.9$ & Good & 41 & 37 & 13.67 & 12.33 \\
\hline $40-49.9$ & Fair & 68 & 62 & 22.67 & 20.67 \\
\hline $0-39.9$ & Poor & 166 & 171 & 55.33 & 57.00 \\
\hline & Total & 300 & 300 & 100 & 100 \\
\hline
\end{tabular}

Table1 shows that the students perceived the environmental characteristics as being highly related to their academic performance in integrated science. About $85.33 \%$ of the students agreed with the opinion expressed in the questionnaire while only $4.01 \%$ disagreed with the expressed opinion.

Table2 shows that the percentage of females who agreed with the opinion expressed is higher than that of the male students. The male students have a higher percentage of undecided opinion compared to the female students and only $2 \%$ of the females disagreed with the expressed opinion while $6 \%$ of the male disagreed with the opinion.

Table 3 provided information about the mean score $(\bar{x})$ of each item of the questionnaire. Ten (10) items have mean score range of 2.3 - 30 while eight (8) items were disagreed with by students and only 2 items were rated as uncertain by the students.

\subsection{Hypotheses Testing}

Hypothesis one: There is no significant difference between the mean perception score for male and female students.

The result of the Z-test statistics computed using the differences of mean perception score for male and female students is presented in table 4:

Table4. Mean score standard distribution and Z-score calculated values on perception of male and female students.

\begin{tabular}{|l|c|c|c|c|c|c|}
\hline Sex of students & $\mathrm{N}$ & Mean score & SD & Z-cal & Z-cri & P \\
\cline { 1 - 5 } Male & 300 & 61.5 & 10.00 & & & \multirow{2}{*}{0.81} \\
\hline Female & 300 & 63.8 & 6.94 & -3.29 & 2.81 \\
\hline
\end{tabular}

Significant at $\mathrm{P}<0.05$ level

Since $/ Z />Z_{2}^{\alpha}$ that is $/-3.29 />2.81$, we reject the null hypothesis. We therefore conclude that there is significant difference between the mean perception score for male and female. The mean perception for female is higher than that of male.

Hypothesis Two: There is no significant correlation between the students perception of environmental characteristics and their achievement in integrated science. The result of the PearsonProduct Moment correlation Coefficient ( $r$ ) computed using deviation from mean method is presented in table 7 below.

Table7. Pearson Product Moment Correlation statistical Analysis on perception of Environmental characteristics and student Achievement in integrated science.

\begin{tabular}{|l|l|l|l|l|l|l|l|}
\hline Variable & $\mathrm{N}$ & Total score & Mean score $(\bar{x})$ & SD & r-cal & r-cri & P \\
\hline Student perception & 600 & 37584 & 62.64 & 8.67 & 0.34 & & \\
\cline { 1 - 5 } Students achievement & 600 & 20510 & 34.18 & 16.96 & & 0.1946 & 0.05 \\
\hline
\end{tabular}


As indicated in table 7, the calculated $r=0.34$ was greater than the table $r=0.1946$. Hence the null hypothesis was rejected. This implies that there was significant difference between the students perception of the environmental characteristics and their achievement in integrated science.

\subsection{Discussion of Results}

The result and findings of the study show that the female students perform better than the male students in integrated science and that the environmental characteristics are some of the factors contributing to poor academic performance. The environmental characteristics perceived by the students themselves to be related to the learning academic performances in integrated science are too much activities and student engagement in errands, trading, farming, fishing and so on, lack of proper place to study, to much domestic work at home, and no provision for lesson teachers at home.

Other environmental characteristics perceived by the students are disturbance from siblings and peers at home, lack of adequate reading materials in integrated science, lack of adequate supervision of students work both at home and in school, noisy environment at home make it unconducive for learning and lack of interest by parents about their children's academic success.

\section{CONClusion}

It was concluded that students perceived environmental characteristics as being related to the academic achievement of students in junior secondary school in integrated science and that these environmental characteristics are influencing poor academic performance of the students. The results of this study seems to support earlier studies such as [7], [10], [11], [12], [9] who argued that students perceived environmental characteristics has a substantially great effect on learning outcomes in integrated sciences.

\section{RECOMMENDATIONS}

Based on the findings made and conclusions reached, the following recommendations were made:

- There is need for constant interaction between the parents and teachers, and in some cases between parents, teachers and the students. This can be done by making it compulsory for each school to organize a stakeholders meeting at least twice in an academic session in order to provide an avenue for parents to be enlightened on how to make homes cohesive for learning.

- The government should make sure that every school have a counseling unit and facilities should be provided for the unit.

- Stakeholder in education industry should meet constantly to discuss issues concerning teaching and learning environment of students particularly integrated science in junior secondary school levels.

\section{REFERENCES}

[1] Margan, West (2007). Instructional design, implications from cognitive Science. New Jersey: Pearson Education company.

[2] Federal Republic of Nigeria (2004). National Policy on Education. Lagos: NERDC press.

[3] Okafor, P. (2008). Science anxiety as a function of gender and experience. Sex Roles, 42 (1-2), 119-131.

[4] Chapman O. J. (2010). Curriculum development. New York: American books Ltd, 25-27,35.

[5] Liberman, B. (2012). Use of Integrated Science and teaching Londom: Longman Publishers.

[6] Okoye, E. (2004). Principles and Ibadan: Evans Publishers.

[7] Hassan, T. (2012). Psycho-social predictor of academic performance in Nigeria secondary school students. A paper presented at the joint Higher Degree students seminar of the department of Teacher Education.

[8] Gartside, M. (2008). Environmental effects on the Nigeria National Common Entrance Examinations to secondary school. TEDRO, (WAEC).

[9] Iweka, Fidelis (2017). Educational Research Methods and Statistical techniques. Omoku: CHIFAS Nigeria.

[10] Ezewu, E. E. (1983), sociology of Education: Ibadan: Published by Institute of Education, University of Ibadan. 
[11] Atakpa, R. A. (1997). Parental attitude towards female students participation in Integrated science education in Nigeria. (A case study of Ika South Local Government Area Delta State) University of Benin Unpublish PGR project.

[12] Evroro, E. S. (2007). The influence of home environment on the learning of business studies in Junior Secondary Schools in Delta State. Journal of Science and Technology Research (JSTR-2007-93).

\section{AUTHOR'S BIOGRAPHY}

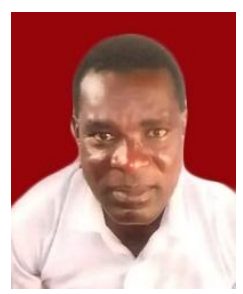

Dr. Iweka Fidelis is a Senior Lecturer in the Department of Educational Psychology, Guidance and Counseling, University of Port Harcourt, Rivers State in Nigeria. He is a specialist in Psychometrics and a consultant in Research Methods and Statistical Techniques. He has published extensively and intensively on Psychometrics both internationally and nationally.

Citation: Iweka, Fidelis (Ph.D). "Students' Perception of the Influence of Environmental Characteristics on the Academic Performance of Students in Integrated Science in Rivers State" International Journal of Humanities Social Sciences and Education (IJHSSE), vol 5, no. 4, 2018, pp. 46-51. doi: http://dx.doi.org/10. 20 431/2349-0381.0504004.

Copyright: () 2018 Authors. This is an open-access article distributed under the terms of the Creative Commons Attribution License, which permits unrestricted use, distribution, and reproduction in any medium, provided the original author and source are credited. 